\title{
Regulatory framework analysis for the unmanned inland waterway vessel
}

\author{
Wa Nzengu ${ }^{1}$ - Jérôme Faivre ${ }^{1} \cdot$ Ann-Sofie Pauwelyn $^{2} \cdot$ Victor Bolbot $^{3}$ (D) \\ Lars Andreas Lien Wennersberg ${ }^{4} \cdot$ Gerasimos Theotokatos $^{3}$
}

Received: 22 December 2020 / Accepted: 22 April 2021/ Published online: 27 May 2021

(C) The Author(s) 2021

\begin{abstract}
Several research and innovation initiatives have been pursued worldwide for the development of autonomous and unmanned ships. However, these ships' wider adoption is limited by the existing regulatory framework, which presently does not provide clear guidelines and requirements for the design and operation of autonomous ships. The aim of this study is to comprehensively analyse the existing maritime safety and security regulatory framework including the national and international regulations for designing, building, testing and operating the unmanned next-generation inland waterways (IWW) vessel considered in the AUTOSHIP project operating in the Flemish inland waters. This study initiates with the identification of the regulatory bodies controlling the operation and testing of the investigated vessel and then identifies barriers in regulations where amendments or new developments are required. Subsequently, a strategy for overcoming these barriers is proposed. The main regulatory gaps that are identified include the requirements for navigation, emergency and environment protection functions, where new definitions are required for unmanned ship operations (e.g. master, crew, remote control centre). Moreover, some of the regulations explicitly specify the existence of crew on the ships for navigation, emergency and environment protection functions. A three-phase strategy is proposed to overcome the current regulatory barriers.
\end{abstract}

Keywords Inland waterway ship · Regulatory framework · Autonomous ships · Safety · Security

\section{Introduction}

The future of waterborne logistics in Europe relies on the maritime industry's ability to both improve their cost-efficiency and reduce their environmental impact. One of the

Victor Bolbot

victor.bolbot@strath.ac.uk

Extended author information available on the last page of the article 
measures that the maritime industry has identified as promising is the use of remote and autonomous ship technology, which holds great potential for safety, environmental and efficiency improvements (de Vos et al. 2021; Rødseth and Burmeister 2015; Wróbel et al. 2017). It is anticipated that autonomous shipping will contribute to alleviate the expected deficit of seafarers and also reduce the barriers for women employment in the maritime industry (Kim et al. 2019). Major industrial initiatives on building commercial autonomous ships are ongoing, such as Yara Birkeland (Yara 2018) and ASKO (Smartmaritime 2020), whereas several research projects (completed and ongoing), such as MUNIN (MUNIN 2016), AAWA (AAWA 2016), SISU, SVAN (Daffey 2018), the Revolt concept (Tvete 2015), the Design for Value (DIMECC 2018), SFI AUTOSHIP (SFI AUTOSHIP 2021), AEGIS (AEGIS 2021) and AUTOSHIP (AUTOSHIP 2019), have been developing and testing new concepts and technologies building towards the next-generation autonomous shipping. Despite the increasing industrial interest and the recent technological advances, the maritime industry will not be able to reap the full benefits of this technology before several barriers are overcome. The regulatory framework has been identified as one of the most crucial barriers (AUTOSHIP 2019).

The present regulatory framework governs the safety and security of conventional ships and their onboard crew, but the crew will be moved from ship to shore through the use of remote and autonomous ship technology. This disruptive shift will lead to new ship designs (MUNIN 2013), new roles for the crew, new interactions with the crew (Bolbot et al. 2019) and new management procedures and leadership schemes (Kim and Mallam 2020), as well as new cybersecurity hazards (Bolbot et al. 2020). These are not explicitly addressed by the present maritime regulations (neither at IMO nor at inland waterway regulatory level), as the key regulatory instruments are based on the assumption that the crew is present on board ships. The lack of explicit regulations is an obstacle for autonomous ship adoption, and hence, the maritime industry relies on policy makers to develop regulations that support safe and secure operations of unmanned ships. The question that still remains to be answered is how the regulatory framework must be modified or amended to address existing limitations.

The regulatory gaps and barriers associated with autonomous ships have received attention in several studies and research projects, in which most of them have focused on coastal short sea and deep-sea shipping. The MUNIN project (MUNIN 2013) analysed the international and UK national regulations for a short sea shipping case. Lemon (Nick 2013) investigated the adoption of the unmanned vessels under the scope of Australian legislative framework, whereas the Danish Maritime Authorities (DMA 2017) analysed the regulatory barriers existing in Danish law together with the international legislation that have been transferred to Danish law. Comité Maritime International (CMI 2016) published their own position on the present international legal framework. Ferreira et al. (2018) investigated whether the European Parliament report on robotics is relevant for a small autonomous craft operating in Italian coastal waters. Fastvold (2018) examined the legal challenges for the adoption of unmanned ships in the international law. The International Maritime Organisation (IMO 2020) organised a regulatory scoping exercise for analysis of its existing regulatory instruments, and this is planned to continue in next safety committee meeting (MSC 103). Ringbom (2019) contributed to the regulatory scoping exercise implemented by IMO. Karlis (2018) elaborated on a number of international regulatory issues with respect to autonomous 
ships. Van Hooydonk (2014) examined the United Nations convention on the law of the sea in connection with autonomous ships. Komianos (2018) provided an overview of important international regulations and associated challenges/gaps related to autonomous ships. The regulatory framework for application and testing of autonomous ships in Baltic state was analysed by Henrik et al. (2020).

The results of these regulatory studies cannot, however, be directly applied to inland waterway shipping. This stems from the fact that the inland waterway ships, their operations and their context differ significantly from short sea and ocean-going ship applications. The difference is also reflected by the different policy makers governing the regulatory framework for ocean-going and coastal shipping, where IMO is the main regulatory body, whilst various other policy makers govern the regulatory framework for inland waterway shipping.

Inland waterway regulations in Europe are governed by several policy makers on both regional and national levels. It has been pointed out that there is a need for further improvements and harmonisation of these regulations (Erceg 2018) and the introduction of autonomous ships will contribute to this need. According to the pertinent literature review, only few studies focused on the IWW vessels. Bačkalov (2020) analysed some of the EU inland waterway regulations with respect to autonomous ships. Erasmus School of Law (2019) analysed the relevant regulations in Netherlands, identifying the regulatory gaps and barriers for an unmanned vessel with respect to safety and the changes in the human role, resulting in a set of high-level recommendations for future regulatory development steps.

However, several regulations remain to be analysed to understand the full impact of the introduction of autonomous ship technology on the regulatory framework for the inland waterways transport. It should also be acknowledged that the process of developing new regulations or amending existing regulations is time demanding at both regional and national levels. To this end, it is of immense importance to identify the most critical gaps and barriers that should be prioritised, as well as to consider whether provisional regulations and legislation, such as bi-lateral agreements, could speed up this process.

The aim of this study is to analyse the safety and security regulatory framework in order to provide recommendations to the inland waterways' policy makers, such as flag states, UNECE (United Nations Economic Commission for Europe) and CCNR (Central Commission for the Navigation of the Rhine), on the most important regulatory gaps and barriers required for the introduction of unmanned ships in inland waterways transport. The provided recommendations are based on a case study analysis of a pallet shuttle barge (PSB) that operates in Flemish rivers and canals. This barge is planned to be rebuilt from its conventional form to an autonomous mode supported by a remote control centre at the framework of the AUTOSHIP project as demonstrator of autonomous technology. The applicable regulations for its design, construction and operation are analysed with respect to safety, security and cybersecurity.

The novel elements of the present research include: (a) the identification of all relevant regulatory bodies for the specific case study vessel; (b) the identification of additional European level regulations that would apply to the investigated vessel; (c) the identification of the regulatory gaps and barriers for CCNR autonomy level 3 and above (CCNR 2018), corresponding to the supervisory control mode, DA2 degree of automation, $\mathrm{OC} 0$ onboard control level and $\mathrm{RC} 1 / \mathrm{RC} 2$ remote control level according to the AUTOSHIP project guidelines (Rødseth et al. 2020); and (d) the proposed strategy to overcome these gaps and barriers for the investigated vessel testing and operation. 
The remainder of this study is structured as follows. Section 2 describes the methodological approach for the regulatory analysis. This is followed by a description of the case study, with particular emphasis on vessel characteristics, operating area and the owner requirements in Section 3. The results of the analysis including the regulations that have been analysed and the identified gaps and barriers are given in Section 4. Section 5 provides recommendations to policy makers and includes proposals to close the gaps and remove the barriers. Finally, the main findings and conclusions of this paper are presented.

\section{Methodological approach}

The identification of gaps and challenging requirements in the existing regulatory framework for the implementation of the autonomous and unmanned vessels technology was carried out according to the methodological approach described in the flowchart of Fig. 1.

The main inputs are the vessel specifications and the vessel owner requirements including the information and data, such as the main vessel particulars, the operating areas, the intended mission, the work organisation, the operating method and adopted technical solutions for the vessel operation (level of automation, maintenance method, etc.).

Analysis of the acquired input allows for identifying and mapping the relevant regulatory authorities competent to permit the investigated vessel operation in the demonstration area during step 1 . In step 2 , the existing regulatory compliance framework in the operating areas of interest is identified, including the prevailing regulations, rules and standards (regional and national) for the design, building, testing and operation with respect to safety and security. The gaps and challenging requirements are identified in step 3 through the use of the following means: (a) a thorough review of the regulatory compliance framework; (b) accounting for the outcomes of interviews with stakeholders conducted within the scope of the AUTOSHIP project; and (c) incorporating results of other similar projects (literature review). The outcomes of interviews and literature review allowed for collecting the opinions of inland waterway transport operators, and experienced skippers, the expectations of insurance companies, as well as the expectations and perspectives of regulatory bodies. Recommendations to overcome the existing regulatory barriers are provided in step 4.

\section{Investigated vessel characteristics}

This study considers the use case of a pallet shuttle barge (PSB) to elaborate on the regulatory framework analysis taking into account the PSB characteristics, the

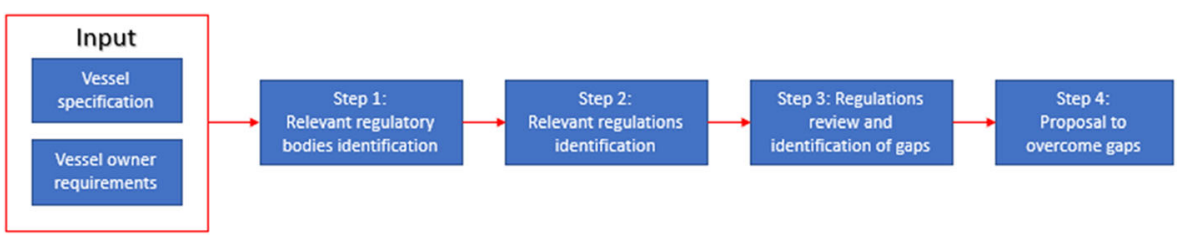

Fig. 1 Methodological approach 
operating area characteristics, the role of the PSB in the supply chain, the operator requirements and the corresponding automation level targets.

\subsection{Pallet shuttle barge}

The present analysis is based on the Conférence Européenne des Ministres des Transports (CEMT) class 2 PSB that has an overall length of $50 \mathrm{~m}$, a breadth of 6.7 $\mathrm{m}$ and a draught of $2.2 \mathrm{~m}$. A picture of the PSB is shown in Fig. 2. It has a monohull design with a flat cargo deck located above the waterline. A moveable gantry crane is located on the cargo deck. The gantry crane can reach the whole deck area, thus rendering the barge independent of shore-based infrastructure for loading and offloading of goods.

The wheelhouse, or control cabin, is located at the fore. The main propulsion and steering is provided by an azimuth thruster with a fixed pitch propeller at the aft. Additional steering capability at low speeds is provided by an azimuth thruster with fixed pitch propeller at the bow. The main propulsion power is provided directly from a dedicated diesel engine through a shaft, whereas the auxiliary power and the bow thruster power are provided through a diesel-electric power system that also can be connected to shore to power auxiliaries during night-lay.

The ship is designed to be operated by a single person crew. This one crew needs to have necessary qualifications to navigate the barge and operate the crane for loading and offloading of goods. The crew also needs to have necessary qualifications to perform simple assessments and measurements on technical equipment, but no qualifications for technical service and maintenance are needed, as the barge is always easily accessible from shore. The barge is, in special cases, operated with two personnel, when the single crew does not possess necessary qualifications or if regulations for specific rivers, canals or regions require more than one crew onboard the ship.

\subsection{Operating area}

The PSB operates between smaller ports and quays along rivers and canals in the Flemish Region. Larger ports and harbours, such as its home port Antwerp, are avoided due to the

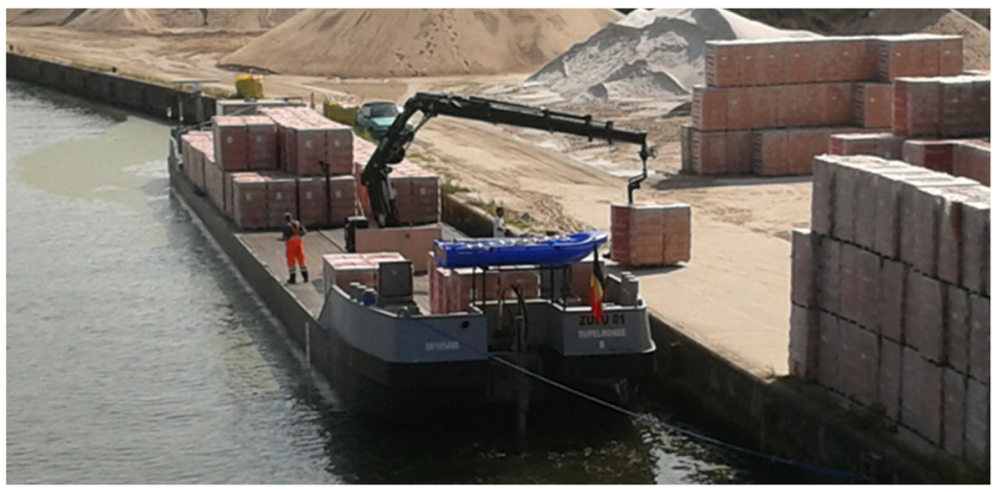

Fig. 2 IWW - Pallet shuttle barge 
requirements of using onshore personnel for loading and offloading of goods. The rivers and canals that the can operate on are given by its CEMT2 classification. It is normally allowed to sail between the hours 6 a.m. and 10 p.m., but variations to this exist.

The quays that the PSB services can be divided into two main categories: quays in tidal rivers and quays in non-tidal canals. The tidal rivers impose a significant current up to $7 \mathrm{~km} / \mathrm{h}$ and affect the barge operation as the water level difference can be up to 6 $\mathrm{m}$.

There are several water locks, fixed bridges and movable bridges in this operating area. The fixed bridges cannot be opened or moved and impose a fixed height restriction, ranging from $1.56 \mathrm{~m}$ to "no restriction" relative to the normal water level. The movable bridges can impose height restrictions when closed, whereas they do not impose high restrictions when opened. Passing under bridges or through water locks requires that the barge communicates with the bridge or lock control personnel. The personnel can either be located on the site or remote, which can give different opening hours for locks and bridges that must be considered.

Specifically, for the AUTOSHIP project, the converted PSB will sail in an area south of Antwerp (Fig. 3). This route is also sailed today with crewed barges. The voyage would start at the river Scheldt, which is a CEMT class VI and tidal river (point A). The PSB would sail to point B, the Wintam sea lock, which accommodates both inland waterway vessels and sea sailing ships. Then, it follows the Sea Canal to the south, and it needs to pass an automated train bridge (point $\mathrm{C}$ ) and an automated road bridge (point D). Point E is a small automated bridge and from there onwards the canal accommodates only CEMT class 2 vessels. Point $\mathrm{F}$ is a harbour for pleasure crafts. Point $G$ is the CEMT class II lock KleinWillebroek. At point $\mathrm{H}$, there is a ferry for passengers and bikes crossing the canal throughout the year. It goes back and forth every 30 min every working day. After that, the ship enters the tidal river Rupel, which is a CEMT class V river. It will pass the bridges again (points I and J) and at the end when Rupel flows into the Scheldt, there is another ferry that also sails back and forth every half an hour (point K).

\subsection{Supply chain and transport system characteristics}

The PSB is specially designed to transport palletised goods and big-bags over short to medium ranges. It can also transport 20 -ft roller containers and construction components, but that will require other means than the onboard gantry crane for loading and offloading. The barge operates in a point-to-point transport system and provides transportation service in a wide range of supply chains and for a wide range of customers. Although the value chain of PSB includes several processes, such as tender process and fleet management, planning and land transport integration, this analysis focuses on the waterborne transport carried out by the barge. Waterborne transport can be divided into five distinct operational phases (Wennersberg and Nordahl 2019), as illustrated by Fig. 4. The regulatory analysis of this study has targeted the following phases: (a) depart location, (b) sail to next location and (c) approach location. These are the phases, which are linked to the requirements for autonomous operations set by the operator of the PSB. 


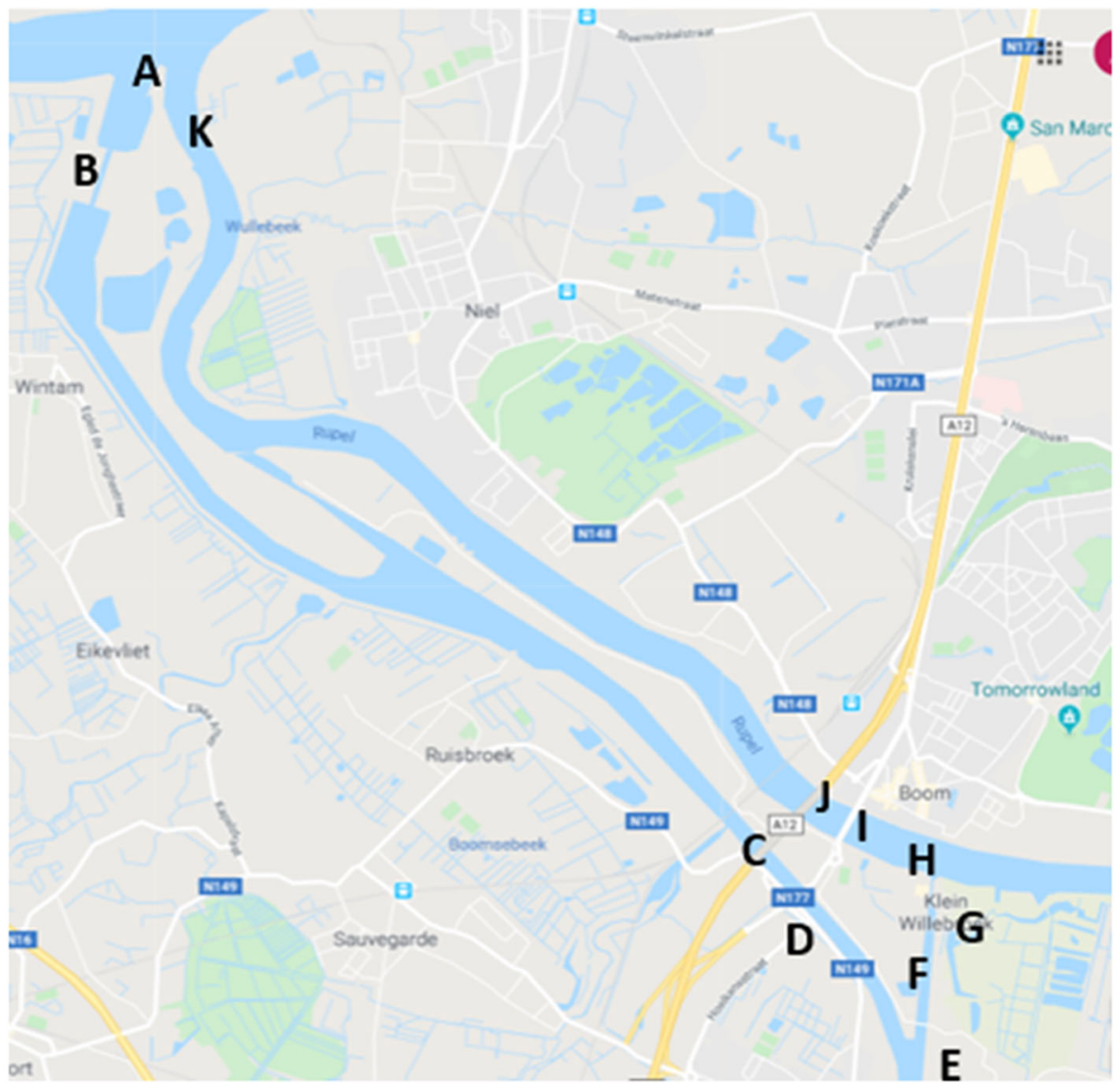

Fig. 3 AUTOSHIP test area. Adapted from (Google maps 2020)

\subsection{PSB owner requirements}

The owner targets at removing the crew from the ship and thus transforming the operations from crewed to unmanned. This target applies to the operational phases depart location, sail to next location, approach location and a subset of the activities in the phase activities at location. The barge will, in the beginning, depend on the onshore

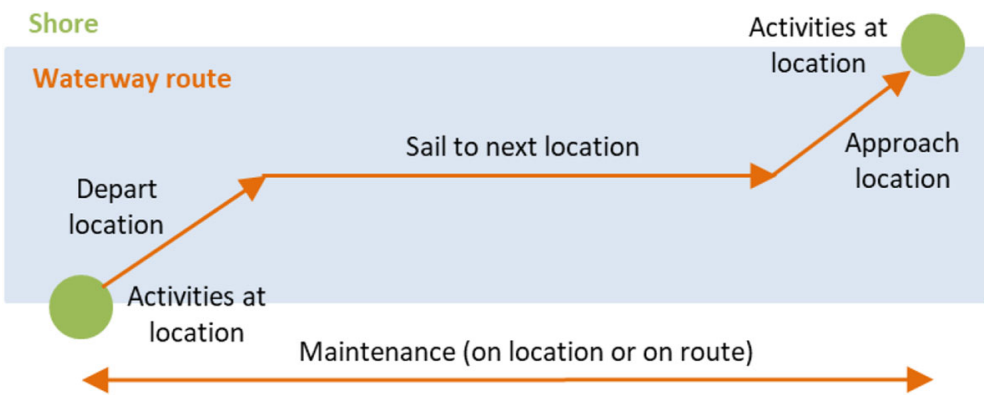

Fig. 4 The five phases of waterborne transport (Wennersberg and Nordahl 2019) 
crew or automated cargo handling equipment for loading and offloading. The same applies for mooring. It is also assumed that most maintenance activities will continue as before, since the barge always will be easily accessible from land. The owner also expects to operate the ships $24 \mathrm{~h}$ each day, and thus challenge existing regulations on the operating timelines on the canals, rivers, bridges and water locks.

\subsection{Automation level target}

The combination of the owner requirements and the operational phases (depart location, approach location and sail to next location) has been transformed to a target automation level corresponding to constrained autonomous operations. This is equivalent to minimum CCNR Level 3. This also corresponds to the supervisory control mode, DA3 degree of automation, OC0 onboard control level and RC1/RC2 remote control level from the AUTOSHIP project (Rødseth et al. 2020).

\section{Results and discussion}

\subsection{Step 1: Regulatory body overview}

The relevant authorities and regulatory bodies are provided schematically in the flowchart of Fig. 5.

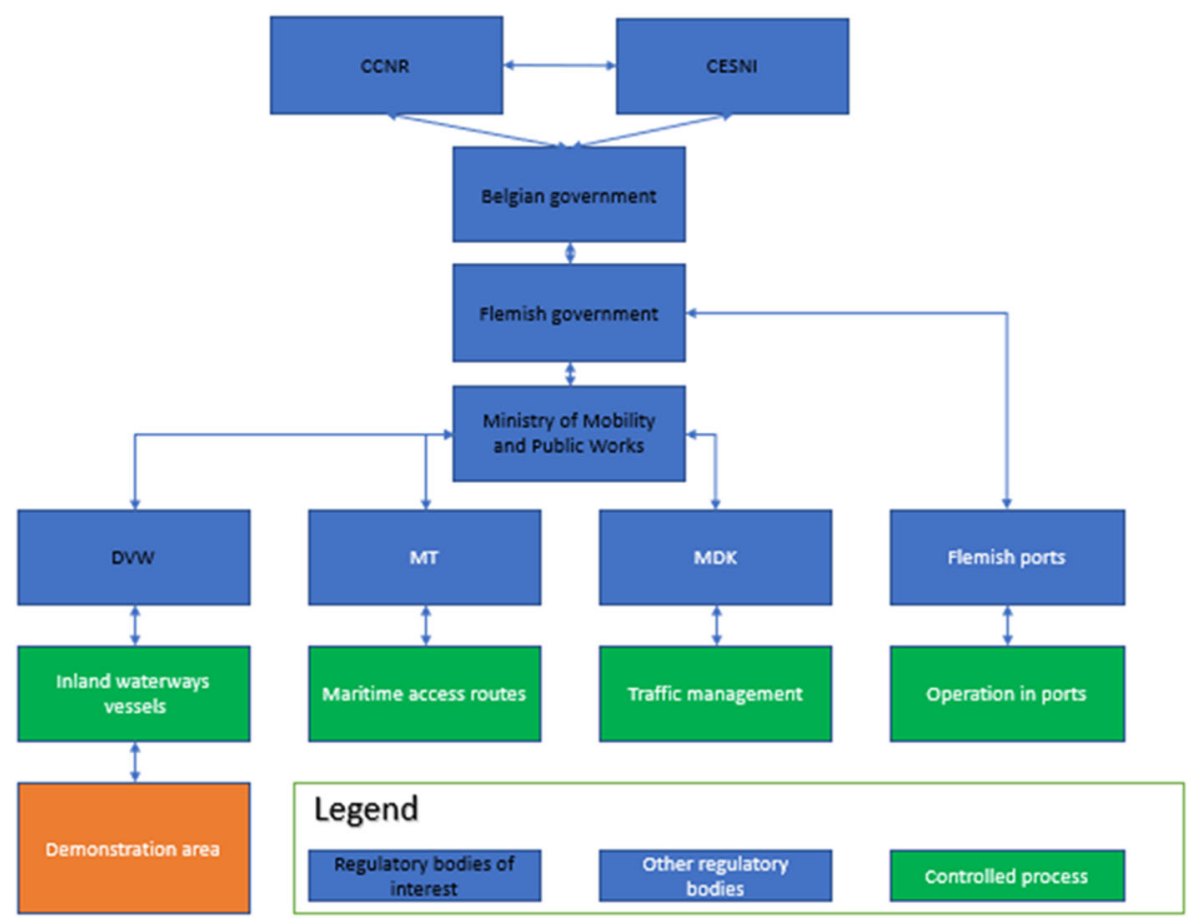

Fig. 5 The relevant regulatory bodies of interest 
There are three main waterway authorities in Flanders. They are responsible for the construction and maintenance of the waterways and their banks, locks, bridges and towing paths.

- De Vlaamse Waterweg NV (DVW) is responsible for the inland navigation.

- Maritieme Toegang (MT) is responsible for the managing and maintaining of the waterways leading to the seaports of Antwerp, Ghent, Ostend and Zeebrugge, the so-called maritime access routes.

- Maritieme Dienstverlening en Kust (MDK) is responsible for the traffic safety management on the maritime access routes.

The Flemish ports are responsible for the waterways in their territory.

The area where the demonstration with the PSB will take place is located on the waterways under the responsibility of DVW. The Ministry of Mobility and Public Works is responsible for preparing a part of the law concerning inland waterways. The Flemish Government approves the law in the form of decrees.

Flanders has adopted the European standard for establishing the technical regulations for inland vessels (ES-TRIN). This standard was developed by CESNI (Comité Européen pour l'Élaboration de Standards dans le Domaine de Navigation Intérieure), a cooperation between Member States of the European Union, the CCNR (Central Commission for Navigation on the Rhine) and representatives of international organisations focusing on inland navigation. The goal of CESNI is to simplify the rules and regulations for inland waterways and to share knowledge between the different members to achieve a standardised approach for inland waterways. Exceptions can only be granted based on the advice from CESNI. The exception would be then valid for the whole European Union.

\subsection{Step 2: Relevant regulation overview}

A mapping of the rules and regulations applicable to the IWW use case and covered by the investigation is given in Table 1 and a short description of these regulations is provided below.

The European Directive 2016/1629/EC (CESNI 2017) refers to European Standard laying down Technical Requirements for Inland Navigation vessels (ESTRIN). ESTRIN is mandatory both for European Union countries and CCNR countries.

The European Directive 2008/68/EC (UNECE 2019) refers to the Annexed Regulations of the European Agreement concerning the International Carriage of Dangerous Goods by Inland Waterways (ADN). The IWW use case does not include the carriage of dangerous goods. The European Directive 2008/68/EC has therefore not been considered.

As the ship is operating on Rhine connected canals, regulations relevant to Rhine convention are applicable here. The RPNR contain navigation police provisions drawn up by the CCNR police regulation committee. The regulations for the Rhine navigation personnel (RPN) provide a framework defining the crew member minimum number, qualification, training and resting time. 
Table 1 IWW mapping of rules and regulations

\begin{tabular}{|c|c|c|}
\hline Rules/regulations & Purpose & Regulatory body \\
\hline $\begin{array}{l}\text { European Directive } \\
\text { 2016/1629/EC [24] }\end{array}$ & $\begin{array}{l}\text { European Standard laying down } \\
\text { Technical Requirements for } \\
\text { Inland Navigation vessels (ESTRIN) }\end{array}$ & CESNI \\
\hline $\begin{array}{r}\text { European Directive } \\
2008 / 68 / \mathrm{EC}[25]\end{array}$ & $\begin{array}{l}\text { Annexed Regulations of the European } \\
\text { Agreement concerning the } \\
\text { International Carriage of Dangerous } \\
\text { Goods by Inland Waterways (ADN) }\end{array}$ & UNECE \\
\hline \multirow[t]{2}{*}{ Rhine convention } & $\begin{array}{l}\text { Police Regulations for the Navigation } \\
\text { of the Rhine (RPNR) }\end{array}$ & CCNR \\
\hline & $\begin{array}{l}\text { Regulations for the Rhine Navigation } \\
\text { Personnel (RPN) }\end{array}$ & CCNR \\
\hline $\begin{array}{r}\text { European Directive } \\
1996 / 50 / \mathrm{EC}[26]\end{array}$ & $\begin{array}{l}\text { On the harmonisation of the conditions } \\
\text { for obtaining national boat masters' } \\
\text { certificates for the carriage of goods } \\
\text { and passengers by inland waterway in } \\
\text { the community }\end{array}$ & CESNI \\
\hline $\begin{array}{l}\text { European Directive } \\
\text { 2014/112/EC [27] }\end{array}$ & $\begin{array}{l}\text { Implementing the European Agreement } \\
\text { concerning certain aspects of the } \\
\text { organisation of working time in inland } \\
\text { waterway transport }\end{array}$ & CESNI \\
\hline $\begin{array}{l}\text { CLNI - Strasbourg } \\
\text { convention of } 2012 \text { [28] }\end{array}$ & $\begin{array}{l}\text { Convention on the limitation of liability } \\
\text { in inland navigation (CLNI) } 2012\end{array}$ & CCNR \\
\hline $\begin{array}{l}\text { CDNI - Strasbourg } \\
\text { convention of } 1996 \text { [29] }\end{array}$ & $\begin{array}{l}\text { Convention on the collection, deposit and } \\
\text { reception of waste generated during } \\
\text { navigation of the Rhine and other inland } \\
\text { waterways (CDNI) }\end{array}$ & CCNR \\
\hline $\begin{array}{l}\text { Resolution } \mathrm{N}^{\circ} 24-\text { European } \\
\text { Code for Inland Waterways } \\
(\mathrm{CEVNI})[30]\end{array}$ & $\begin{array}{l}\text { European Code for Inland } \\
\text { Waterways - CEVNI adopted on } \\
15 / 11 / 1985 \text { (the identified challenges } \\
\text { are similar to the RPNR code) }\end{array}$ & UNECE \\
\hline $\begin{array}{l}\text { Belgian Royal Decree of } \\
24 / 09 / 2006[31]\end{array}$ & $\begin{array}{c}\text { General Police Regulations for the } \\
\text { navigation of the Belgian IWW }\end{array}$ & Belgian government \\
\hline Specific regulations & $\begin{array}{l}\text { Ship Navigation Regulations for the } \\
\text { Brussels-Scheldt Canal }\end{array}$ & Belgian government \\
\hline
\end{tabular}

The European Directive 1996/50/EC (European Commission 1996) harmonises the conditions for obtaining national boat masters' certificates for the carriage of goods and passengers by inland waterway in the Community.

The European Directive 2014/112/EC (European Commission 2014) implements the European Agreement concerning certain aspects of the organisation of working time in inland waterway transport.

The Central Commission for the Navigation of the Rhine (CCNR) initiated the Strasbourg Convention on the limitation of liability in inland navigation (CLNI) 1988 based on the model of the convention on the limitation of liability for marine claims (LLMC). The Strasbourg Convention of 2012 [28] modernised and repealed the Strasbourg convention of 1988 . The purpose is to allow ship owners and crew members of inland vessels and their salvors to set a maximum amount to limit their liability in 
respect of claims made in connection with a single incident. The application of the CLNI convention to the autonomous vessels seems to raise no issues regardless of the level of automation.

The Strasbourg Convention on the collection, deposit and reception of waste generated during navigation on the Rhine (CCNR 1996) and other inland waterways was signed on 9 September 1996. The main objective of this Convention is to protect the environment and to improve safety in inland navigation.

The European Code for Inland Waterways [30] is drawn up by the UNECE (United Nations Economic Commission for Europe) and covers police regulations for the navigation of European inland waterway network. The problems raised by the applicability of the CEVNI Code to the autonomous vessel concept are similar to those related to the applicability of the RPNR.

The Belgian Royal Decree of 24/09/2006 [31] regulates the navigation of vessels on inland waterway networks in Belgium. For most waterways, there are special regulations that include site-specific operational provisions. Inside the area that will be used for the AUTOSHIP project IWW demonstrator testing, the special Ship Navigation Regulation for the Brussels-Scheldt Canal also must be followed.

\subsection{Step 3: Regulatory gap analysis}

\subsubsection{European Directive 2016/1629/EC (ESTRIN)}

The areas where amendments or new developments are required and/or other relevant findings for ESTRIN are given in Table 2. These regulations need to be adapted for vessels at CCNR automation level 3 and above. In particular, new technical requirements applicable to smart systems need to be developed.

\subsubsection{Police Regulations for the Navigation of the Rhine (RPNR)}

The areas where amendments or new developments are required for RPNR and/or other relevant findings are given Table 3 . These regulations need to be adapted for vessels at CCNR automation level 3 and above.

\subsubsection{Regulations for the Rhine Navigation Personnel (RPN)}

The areas where amendments or new developments are required and/or other relevant findings for the RPN are given in Table 4. These regulations need to be adapted for vessels at CCNR level 3 and above of automation.

\subsubsection{European Directive 2014/112/EC}

The areas where amendments or new developments are required and/or other relevant findings for the European Directive 2014/112/EC are given in Table 5. These regulations need to be adapted for vessels at CCNR level 3 and above of automation. 
Table 2 ESTRIN review summary

Ref Topic/requirement Remarks/comments

3.03(5) Doors in the aft-peak bulkhead shall be permitted only if it can be determined by remote monitoring in the wheelhouse whether they are open or closed and shall bear the following readily legible instruction on both sides: 'Door to be closed immediately after use'.

3.04(3) All openings in walls, ceilings and doors of engine rooms, boiler rooms and bunker rooms shall be such that they can be closed from outside the room.

4.04 Vessels shall have at least three pairs of draught marks, of which one pair shall be at $1 / 2$ of length $\mathrm{L}$ and the two others located, respectively, at a distance from the bow and stern that is equal to roughly $1 / 6$ of the length L.

7.01.1 Wheelhouses shall be arranged in such a way that the helmsman may at all times perform his task while the vessel is underway.

7.02.1 There shall be an adequately unobstructed view in all directions from the steering position.

7.02.2 The area of obstructed vision for the helmsman ahead of the vessel in an unladen state with half of its supplies but without ballast shall not exceed $250 \mathrm{~m}$. To further reduce any area of obstructed vision, only appropriate auxiliary means shall be used.

7.04.1 It shall be possible to control and monitor the main engines and steering systems from the steering position.

7.06.5a) In wheelhouses designed for radar navigation by one person:

a) The radar screen shall not be shifted significantly out of the helmsman's axis of view in its normal position.

13.03.1 There shall be at least one portable fire extinguisher in accordance with the European Standards EN 3-7: 2007 and EN 3-8: 2007 at a number of the places.

15 This provision requires living spaces for crew.

27.01(2) Stability documents shall provide the boat master with comprehensible information on vessel stability for each loading condition.

27.04 The procedure for assessing stability may be determined by the documents referred to in Article 27.01(2).

28.03(3) For diversified cargo, the stability calculation shall be performed for the most unfavourable

This requirement foresees the remote monitoring of doors in aft-peak bulkhead but does not require any means of remote control of such doors. The doors are to be operated by a human.

This provision does not explicitly allow remote control of openings in walls, ceilings and doors of engine rooms, boiler rooms and bunker rooms. The doors are to be operated by a human.

This provision does not require an automatic way of reading the draught marks (a draught indicating system).

Vessels are operated by a human from the wheelhouse, design of which implies the crew.

This requirement implies an attended steering position on board.

This rule implies that sufficient visibility from the wheelhouse should be attained primarily by design adapted to human perception.

The steering position is located in the vessel wheelhouse.

This requirement implies manned steering position.

This provision implies the presence of crew on board.

This provision implies the presence of crew on board.

It is required that the stability assessment for a given loading condition is to be carried out by the boat master.

The stability assessment procedure implies the involvement of the boat master (or another crew member). 
Table 2 (continued)

\begin{tabular}{|c|c|c|}
\hline Ref & Topic/requirement & Remarks/comments \\
\hline & $\begin{array}{l}\text { loading condition. This stability calculation } \\
\text { shall be carried on board. }\end{array}$ & \\
\hline 30.03 & $\begin{array}{l}\text { A safety rota shall be provided on board craft } \\
\text { equipped with propulsion or auxiliary systems } \\
\text { operating on fuel with a flashpoint equal to or } \\
\text { lower than } 55^{\circ} \mathrm{C} \text {. The safety rota shall } \\
\text { include safety instructions according to (2) } \\
\text { and a safety plan according to (3) of the craft. }\end{array}$ & $\begin{array}{l}\text { The rule implies that the safety organisation on } \\
\text { board vessels using low-flashpoint fuels relies } \\
\text { upon the human operators. }\end{array}$ \\
\hline
\end{tabular}

\subsubsection{CDNI Strasbourg convention of 1996 and CLNI Strasbourg convention of 2012}

The areas where amendments or new developments are required and/or other relevant findings for the European Directive 2014/112/EC are given in Table 6. These regulations need to be adapted for vessels at CCNR level 3 and above of automation. The application of the CLNI convention to the autonomous vessels seems to raise no problem regardless of the level of automation.

\subsubsection{Belgian Royal Decree of 24/09/2006}

The technical annex of the Decree is the General Police Regulations for navigation of inland waterways (RPNE) based on the European Code for Inland Waterways (CEVNI). The Decree is complemented by local regulations applicable to specific inland waterways. The problems raised by the applicability of the Belgian Decree to the autonomous vessel concept are similar to those related to the applicability of the RPNR.

\subsection{Step 4: Recommendations for overcoming the identified gaps}

\subsubsection{An overarching strategy}

This study proposes the adaptation of the three-phase strategy depicted in the flowchart of Fig. 6 for the introduction of inland waterway autonomous ships. The first phase includes the introduction of prototypes of autonomous/unmanned ships. These prototypes will be allowed to operate in the local waters of one or several countries. Their certification and approval will be based on the risk assessment results, focusing on the already identified regulatory gaps provided in previous sections. The operation of the prototype will be then allowed adopting several stringent safety measures based on outcomes of risk assessment.

Phase 2 includes the development of an initial design code for autonomous ships based on the experience and test results from the prototypes and their risk assessments carried out in Phase 1. The code development requires the repetition of the risk assessment process, but employing more accurate and up-to-date data. The design code will employ as input the regulatory gaps and will provide equivalent (with respect to safety) design measures/functions installed on the autonomous/unmanned vessels or 
Table 3 RPNR review summary

\begin{tabular}{lll}
\hline Ref Topic/requirement & Remarks/comments
\end{tabular}

1.02 Boat master

1.03 Duties of other people on board

1.04 General duty of vigilance

1.08 Crew

1.09.1 On board of any vessel underway, the helm must be held by at least one person.

1.09.3 The helmsman must be able to receive and to give This provision implies an attended wheelhouse. all information and orders that arrive at the wheelhouse or depart from it.

4.06 Use of radar: the vessels can only navigate on the radar as long as there is permanently a person holding an approved driving certificate.

6.13.2 If the proposed manoeuvre can or must force other vessels to deviate from or change their speed, the building that wants to turn must, before turning, announce its manoeuvre in useful time, emitting:

(a) "an extended sound followed by a short sound" if he wishes to turn to starboard or

b) "a prolonged sound followed by two short sounds", if he wants to turn to port.

6.32.1 The vessels can only navigate on the radar as long as there is permanently a person holding a Rhine license or an approved driving certificate or recognized as equivalent under the Rhine Navigation Staff Regulations for the sector to be covered, and a certificate of proficiency for radar operation issued or recognized equivalent under his Regulation, as well as a second person who knows how to use the radar.

7.08.1 The operational guard must be permanently on board buildings in the parking.
This provision explicitly requires the presence of a person on board of the ship with the necessary qualifications. This person is also responsible for making sure that everybody follows the regulation.

This provision refers to other people on board of the ship.

Presence of crew on board is required to exercise vigilance.

This provision explicitly requires the presence of enough crew on board.

This provision explicitly requires the presence of a person.

This provision implies the presence of crew on board.

This provision implies the presence of crew on board.

This provision implies the presence of crew on board.

The number of the crew has to be sufficient in the vessel.

Table 4 IWW RPN review summary

Ref Topic/requirement Remarks/comments

3.15 A minimum crew of self-propelled and pushers.

4.01 On board vessels carrying dangerous goods, a person must hold an expert attestation in accordance with model 8.6.2 of the ADN, under 7.1.3.15 and 7.2.3.15 of ADN.
The minimum crew may not be reduced to zero.

An ADN expert should be on board the vessel. 
Table 5 European Directive 2014/112/EC review summary

\begin{tabular}{|c|c|c|}
\hline Ref & Topic/requirement & Remarks/comments \\
\hline $\begin{array}{c}\text { Article } \\
2\end{array}$ & $\begin{array}{l}\text { "for the purposes of this Directive: (i) } \\
\text { 'boatmaster' shall mean the person who has } \\
\text { the necessary aptitude and qualifications to } \\
\text { sail a vessel on the Member States' waterways } \\
\text { and who has nautical responsibility on board; } \\
\text { (ii) 'member of the deck crew' shall mean a } \\
\text { person who has regularly participated in sail- } \\
\text { ing a vessel in inland navigation, including } \\
\text { manning the tiller". }\end{array}$ & $\begin{array}{l}\text { If people work in a Remote Control Centre, this } \\
\text { directive might not be relevant for them as } \\
\text { they work on land. They will fall under the } \\
\text { work time regulations for people who work on } \\
\text { land. }\end{array}$ \\
\hline $\begin{array}{c}\text { Article } \\
7\end{array}$ & $\begin{array}{l}\text { "An applicant must provide proof of at least four } \\
\text { years' professional experience as a member of } \\
\text { the deck crew on an inland waterway vessel". }\end{array}$ & $\begin{array}{l}\text { If people work in a Remote Control Centre, this } \\
\text { directive might not be relevant for them as } \\
\text { they work on land. They will fall under the } \\
\text { work time regulations for people who work on } \\
\text { land. }\end{array}$ \\
\hline
\end{tabular}

infrastructure. During this phase, the wide commercial operation of the autonomous vessels could be allowed.

During Phase 3, the initial design code would be updated based on the safety incidences observed on autonomous/unmanned vessels using the information received from a fleet of autonomous/unmanned vessels. The use of safety precursors is critical herein, to reduce possibility of any large accident. For this purpose, automatic recording systems, more advanced than the current Voyage Data Recorders, would be required.

\subsubsection{Regional level}

In this section, the proposed approach to overcome the regulatory barriers in national level is presented. The Flemish Decree containing various provisions on mobility policy, public works and transport, traffic safety policy and VVM - De Lijn was published on June 24, 2019, and contains a chapter on innovation (Chapter 3). Articles 50 and 51 of Chapter 3 describe the possibility of Flemish waterway authorities to give temporary exemptions on certain rules and regulations to enable tests with innovative concepts. Those concepts may also include automated systems on board ships or on-

Table 6 CDNI review summary

\begin{tabular}{|c|c|c|}
\hline Ref & Topic/requirement & Remarks/comments \\
\hline & $\begin{array}{l}\text { To achieve environmental protection, the } \\
\text { Convention aims at improved checking of any } \\
\text { waste that occurs, specifically through (i) the } \\
\text { safe and separate collection and subsequent dis- } \\
\text { posal of wastes arising from operating the } \\
\text { vessel, (ii) requiring those causing wastes to pay } \\
\text { the costs of collection and disposal, (iii) the } \\
\text { application of uniform regulations within all } \\
\text { signatory states of the Convention in order to } \\
\text { avoid any unfair competition. }\end{array}$ & $\begin{array}{l}\text { The application of the CDNI convention relies } \\
\text { mainly on the boatmaster. Within the scope of } \\
\text { the CDNI convention, "boatmaster" means the } \\
\text { person under whose authority the vessel is } \\
\text { placed. As there is no further specification about } \\
\text { the location from where the authority is } \\
\text { exercised, the application of the CDNI } \\
\text { Convention may raise problems at level } 3 \text { and } \\
\text { above of automation. }\end{array}$ \\
\hline
\end{tabular}




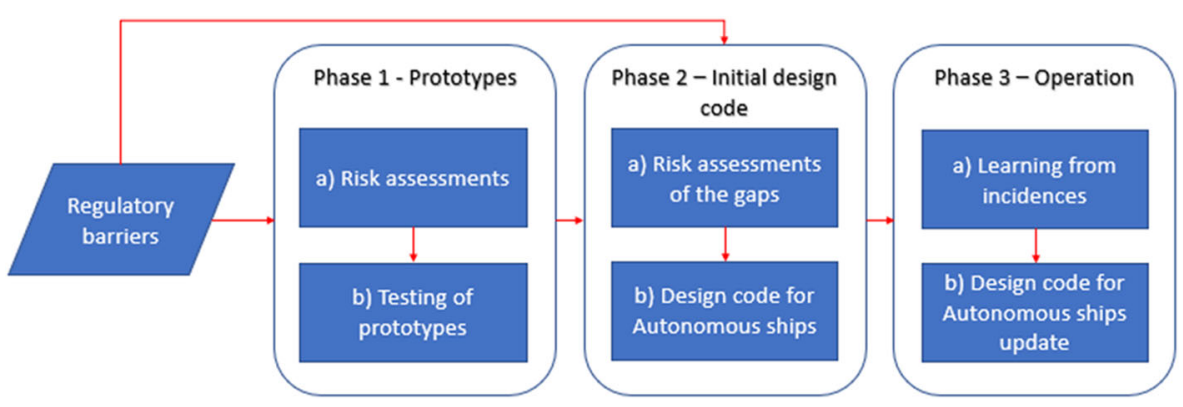

Fig. 6 Suggested strategy for introducing autonomous ships

shore. The temporary exemptions concern rules and regulations about the crew, the navigation of the ship, the technical aspects or the equipment of the ship, the regulation of shipping traffic and the regulations with regard to the activities on board and ashore. The deviations cannot relate to provisions on supervision and enforcement and to provisions of a criminal nature.

For accepting the testing of autonomous ships' prototypes or pilot projects, the following matters must be determined:

i. The purpose of the testing or the pilot project

ii. The waterways, waterway sections or parts of the port area, in which the testing or pilot projects are carried out

iii. The period of the admission

iv. The rules can be exempted/deviated from and, where relevant, the conditions under which these exemptions/deviations are permitted

v. The safety measures taken for the implementation of the testing or the pilot project.

The waterway manager or the port authority may withdraw the acceptance of testing or pilot projects, in whole or in part, if he/she identifies that the safety of crew, assets and environment is affected. Therefore, these proposals need to be complemented by additional recommendations, which must be derived from the outcomes of the MASS operation safety and cybersecurity assessment.

The Flemish authorities are already in Phase 1 of the proposed strategy by this study (Fig. 6). Similar approach can be adopted by the nations interested in testing of autonomous technology in their local waters.

However, there is an immense need to proceed in the next phase (Phase 2 of the proposed strategy) to allow the commercial operation of autonomous ships that incorporate novel technologies. Allowing commercial operation needs another adaptation of the law in the national regulatory framework. This would require the involvement of other national authorities, such as the Ministry of Mobility and Public Works and ports for issuing regulations by the Flemish authorities, similar to the one developed for the conventional ships (a novel design code). The identified regulatory gaps can be addressed by using the principle of equivalent safety with the existing ships and/or the principle of As Low As Reasonably Practical (ALARP) risks. It should also be acknowledged that the process of developing new regulations or amending existing regulations is time-demanding at both regional and national levels. 


\subsubsection{European level}

This section elaborates on the proposals for adoption of the autonomous vessels to overcome the regulatory barriers in European level, which are quite similar with the ones described in the previous section for the Flemish authorities. Within the scope of this analysis, it is important to highlight the existence of Article 25 of the European Directive 2016/1629, which promotes the use of new technologies and derogations for specific vessels in order to encourage innovation (similarly with Flemish decree). This constitutes a legal tool to allow for testing of autonomous vessels in a limited area occupying several European countries in a regional project. Hence, the European regulation level belongs at Phase 1 of the proposed strategy of this study (Fig. 6).

Likewise, with proposals for the national regulatory bodies, the long-term operation of the autonomous and remotely controlled ships in European inland waterways could be ensured, if relevant design codes for autonomous ships are adopted by the pertinent regulatory bodies, such as CESNI and CCNR. Thus, it is crucial to establish a close dialog with these administrations as early as possible. Further development would require the initiation of a working group at CESNI and CCNR level involving experts from a wide range of areas (design, operation, safety, regulatory), which would address the identified gaps, and by considering the existing and novel technologies to develop new regulation guiding the development of autonomous vessels based on the principle of equivalent and ALARP safety.

\section{Conclusions}

In this study, the analysis of the regulatory framework relevant for the operation and testing of an unmanned IWW vessel in the Flemish region was carried out. A strategy that included three phases was proposed as a roadmap for the development of regulatory framework to allow the wider adaptation of autonomous IWW vessels. The main findings of the study include the following:

- Currently, a number of authorities are regulating the operation of the IWW vessel.

- Existing rules and regulations do not allow for the operation of unmanned vessels under Flemish authorities and on European level as they explicitly/ implicitly refer to the presence of humans, so adaptations in the regulations are required.

- More specifically, regulations require the existence of an operator on the vessel for the functions related to navigation, monitoring, emergency and waste management.

- New definitions of responsibilities are required for the IWW operations (e.g. master, crew) and the definition of responsibilities of the Remote Control Centre.

- Existing rules and regulations allow testing of unmanned vessels, but within limited scope and area. Wider area testing would require adaptations of the existing regulations.

- Wider adoption of unmanned inland waterway vessels would require development of novel design codes for autonomous ships at national and European level and their continuous update. 
The identified regulatory gaps and the proposed recommendations to relevant authorities can support the further and faster adoption of the unmanned and remotely controlled ships in European inland waters as the principles presented herein for the adoption of unmanned and remotely controlled ships can be adopted also by other countries. It should be noted though that the analysis does not include all codes and standards relevant for the investigated vessel as the relevant port authorities, the authorities responsible for infrastructure and the vessel traffic management regulations were not considered. This poses directions for future research.

\section{Appendix}

\section{Abbreviations}

ADN Annexed Regulations of the European Agreement concerning the

International Carriage of Dangero
ALARP As Low As Reasonably Practical

CCNR Central Commission for Navigation on the Rhine

CEMT Conférence Européenne des Ministres des Transports

CESNI Comité Européen pour l'Élaboration de Standards dans le

Domaine de Navigation Intérieure

CEVNI European Code for Inland Waterways

CLNI Convention on the limitation of liability in inland navigation

DVW De Vlaamse Waterweg NV

ESTRIN establishing the technical regulations for inland vessels

IWW Inland waterway

LLMC Limitation of liability for marine claims

MDK Maritieme Dienstverlening en Kust

MT Maritieme Toegang

RPN Rhine Navigation Personnel

RPNE Decree is the General Police Regulations for navigation of inland waterways

UNECE United Nations Economic Commission for Europe

Acknowledgements The study was carried out in the framework of the AUTOSHIP project (AUTOSHIP, 2019), which is funded by the European Union's Horizon 2020 research and innovation programme under agreement no. 815012. The authors kindly acknowledge the comments and input with respect to requirements provided from Kongsberg Maritime and ZULU Associates. The authors affiliated with the MSRC greatly acknowledge the funding from DNV AS and RCCL for the MSRC establishment and operation.

\section{Declarations}

Disclaimer The opinions expressed herein are those of the authors and should not be construed to reflect the views of DNV AS, RCCL, Bureau Veritas, DVW, SINTEF or the acknowledged individuals and their associated organisations. 
Open Access This article is licensed under a Creative Commons Attribution 4.0 International License, which permits use, sharing, adaptation, distribution and reproduction in any medium or format, as long as you give appropriate credit to the original author(s) and the source, provide a link to the Creative Commons licence, and indicate if changes were made. The images or other third party material in this article are included in the article's Creative Commons licence, unless indicated otherwise in a credit line to the material. If material is not included in the article's Creative Commons licence and your intended use is not permitted by statutory regulation or exceeds the permitted use, you will need to obtain permission directly from the copyright holder. To view a copy of this licence, visit http://creativecommons.org/licenses/by/4.0/.

\section{References}

AAWA (2016) AAWA project introduces the project's first commercial ship operators. https://www.rollsroyce.com/media/press-releases/2016/pr-12-04-2016-aawa-project-introduces-projects-first-commercialoperators.aspx. Accessed 12/12/2019 2019

AEGIS (2021) What if marine automation can take waterborne transport to the next level? https:/aegis. autonomous-ship.org/. Accessed 25/02/2021

AUTOSHIP (2019) Autonomous Shipping Initiative for European Waters. https:/www.autoship-project.eu/.

Bačkalov I (2020) Safety of autonomous inland vessels: an analysis of regulatory barriers in the present technical standards in Europe Safety Science 128:104763 https://doi.org/10.1016/j.ssci.2020.104763

Bolbot V, Theotokatos G, Boulougouris E, Vassalos D (2020) A novel cyber-risk assessment method for ship systems Saf Sci 131:104908 https://doi.org/10.1016/j.ssci.2020.104908

Bolbot V, Theotokatos G, Bujorianu LM, Boulougouris E, Vassalos D (2019) Vulnerabilities and safety assurance methods in Cyber-Physical Systems: a comprehensive review. Reliab Eng Syst Saf 182:179193. https://doi.org/10.1016/j.ress.2018.09.004

CCNR (1996) Convention on the collection, deposit and reception of waste generated during navigation on the Rhine

Central Commission for the Navigation of the Rhine (CCNR) (2018) Definitions on various forms of automated navigation

CESNI (2017) European Directive 2016/1629/EC - CESNI, European Standard laying down Technical Requirements (ESTRIN.

CMI (2016) CMI International working group position paper on unmanned ships and the international regulatory framework

Daffey K (2018) Technology progression of maritime autonomous surface ships.

de Vos J, Hekkenberg RG, Valdez Banda OA (2021) The impact of autonomous ships on safety at sea - a statistical analysis. Reliab Eng Syst Saf 210:107558. https://doi.org/10.1016/j.ress.2021.107558

DIMECC (2018) D4V - design for value program report. Tampere, Finland

DMA (2017) Analysis of the regulatory barriers to the use of autonomous ships

Erasmus School of Law (2019) Juridisch Onderzoek Smart Shipping.

Erceg BČ (2018) Legal Framework of European Inland Waterways and Croatian Legislation on Inland Waterways Navigation-Problems of Non-Harmonized Rules European Scientific Journal 14:37-57

European Commission (1996) Council Directive 96/50/EC of 23 July 1996 on the harmonization of the conditions for obtaining national boat masters' certificates for the carriage of goods and passengers by inland waterway in the Community

European Commission (2014) Council Directive 2014/112/EU of 19 December 2014 implementing the European Agreement concerning certain aspects of the organisation of working time in inland waterway transport, concluded by the European Barge Union (EBU), the European Skippers Organisation (ESO) and the European Transport Workers' Federation (ETF)

Fastvold OL (2018) Legal challenges for unmanned ships in international law of the sea. UiT Norges arktiske universitet

Ferreira F, Alves J, Leporati C, Bertolini A, Bargelli E Current regulatory issues in the usage of autonomous surface vehicles. In: 2018 OCEANS-MTS/IEEE Kobe Techno-Oceans (OTO), 2018. IEEE, pp 1-9

Henrik R, Mika V, Jussi P, Saara I (2020) Charting regulatory frameworks for maritime autonomous surface ship testing, pilots, and commercial deployments

IMO (2020) Regulatory scoping exercise. https://www.imo.org/en/MediaCentre/HotTopics/Pages/ Autonomous-shipping.aspx. 
Karlis T (2018) Maritime law issues related to the operation of unmanned autonomous cargo ships WMU Journal of Maritime Affairs 17:119-128. https://doi.org/10.1007/s13437-018-0135-6

Kim T-e, Mallam S (2020) A Delphi-AHP study on STCW leadership competence in the age of autonomous maritime operations WMU Journal of Maritime Affairs 19:163-181 https://doi.org/10.1007/s13437-02000203-1

Kim T-e, Sharma A, Gausdal AH, Chae C-j (2019) Impact of automation technology on gender parity in maritime industry WMU Journal of Maritime Affairs 18:579-593 https://doi.org/10.1007/s13437-01900176-W

Komianos A (2018) The autonomous shipping era. operational, regulatory, and quality challenges TransNav: International Journal on Marine Navigation and Safety of Sea Transportation 12

MUNIN (2013) 7.2: Legal and Liability Analysis for Remote Controlled Vessels

MUNIN (2016) Maritime Unmanned Navigation through Intelligence in Networks. http://www.unmannedship.org/munin/. Accessed 12/12/2019 2019

Nick L (2013) Autonomous shipping from regulatory perspective.

Ringbom H (2019) Regulating autonomous ships - concepts, challenges and precedents Ocean Development \& International Law 50:141-169

Rødseth Ø, Burmeister H-C (2015) New ship designs for autonomous vessels. MUNIN project,

Rødseth ØJ, Faivre J, Hjørungnes SR, Andersen P, Bolbot V, Pauwelyn A-S, Wennersberg LA (2020) AUTOSHIP deliverable D3.1 Autonomous ship design standards, Revision 2.0.

SFI AUTOSHIP (2021) SFI AUTOSHIP. https://www.ntnu.edu/sfi-autoship. Accessed 25/02/2021 2021

Smartmaritime (2020) ASKO to build two autonomous vessels for Oslo fjord operations. https:// smartmaritimenetwork.com/2020/09/01/asko-to-build-two-autonomous-vessels-for-oslo-fjordoperations/. Accessed 10/11/2020 2020

Tvete HA (2015) The ReVolt - a new inspirational ship concept.

UNECE (2019) European Directive 2008/68/EC - UNECE. Agreement concerning the International Carriage of Dangerous Goods by Inland Waterways, European

Van Hooydonk E (2014) The law of unmanned merchant shipping-an exploration The Journal of International Maritime Law 20:403-423

Wennersberg LA, Nordahl H (2019) D2.1 - Complete supply chain mapping \& identifications of interactions between SSS and IWW demonstrators.

Wróbel K, Montewka J, Kujala P (2017) Towards the assessment of potential impact of unmanned vessels on maritime transportation safety Reliability Engineering \& System Safety 165:155-169 https://doi.org/10. 1016/j.ress.2017.03.029

Yara (2018) Yara Birkeland press kit. https:/www.yara.com/news-and-media/press-kits/yara-birkeland-presskit/. Accessed 2019/12/12 2019

Publisher's note Springer Nature remains neutral with regard to jurisdictional claims in published maps and institutional affiliations.

\section{Affiliations}

\section{Wa Nzengu ${ }^{1} \cdot$ Jérôme Faivre ${ }^{1} \cdot$ Ann-Sofie Pauwelyn ${ }^{2} \cdot$ Victor Bolbot $^{3} \cdot$ Lars Andreas Lien Wennersberg ${ }^{4} \cdot$ Gerasimos Theotokatos $^{3}$}

1 BUREAU VERITAS Marine \& Offshore, Paris, France

2 De Vlaamse Waterweg, Brussels, Belgium

3 Maritime Safety Research Centre, Department of Naval Architecture, Ocean and Marine Engineering, University of Strathclyde, Glasgow, Scotland

4 SINTEF Ocean, Postboks 4762 Torgard, Trondheim 7465, Norway 